\title{
ON FUNCTIONAL RELATIONS BETWEEN MUNICIPAL AUTHORITIES IN POLAND AND FRANCE*
}

\author{
Monika Augustyniak
}

\begin{abstract}
The article presents the platform of functional relations between the legislative body and the executive body of the municipality in the Polish and French legal order. Reflections made in this respect should help improve the model of both bodies of the municipality in the scope of tasks and competences, shaping the platforms of their joint and separate relations. Determining the manner of implementation of tasks and competences of the municipal bodies based on the principle of cooperation should be an aspiration of the legislator to normatively and factually balance the legal status of both municipal bodies. The analysis of the determinants of the functioning of legislative and executive bodies is aimed at proposing directions of changes in their functional relations, in order to increase the efficiency of their operation as the most important determinant of efficient management of the local community.
\end{abstract}

Key words: functional relations of municipal bodies, division of competences and tasks, legislative and control function, executive function

* Research project carried out at the Faculty of Law, Administration and International Relations at Andrzej Frycz Modrzewski Krakow University financed from funds for statutory activities on the basis of the decision no. WPAiSM/DS/4/2016-KON.

** Prof. nadzw. dr hab. Monika Augustyniak, Associate Professor Andrzej Frycz Modrzewski Krakow University, Faculty of Law, Administration and International Relations at Andrzej Frycz Modrzewski Krakow University. 


\section{FOREWORD}

Both the provisions of the Constitution of the Republic of Poland ${ }^{1}$ and the French Constitution ${ }^{2}$ indicate that the municipality as the basic unit of territorial self-government/ territorial communities performs its tasks through the legislative body and the executive body. In accordance with article 169 par. 4 of the Constitution of the Republic of Poland the internal system of a municipality is determined, within the limits of the acts, by their legislative bodies.

In article 72 par. 3 of the French Constitution, the French legislator has determined that under the rules provided for in the Act the territorial communities may freely exercise their power through elected councils and have the right to issue legal acts in order to exercise their powers. In the Polish and French legal order, the catalogue of municipal authorities is a closed catalogue ${ }^{3}$, which means that its extension by means of subordinate acts is unacceptable.

The subject of this article is the platform of functional relations between the legislative body and the executive body of the municipality in both legal orders. Reflections made in this respect should help improve the model of both bodies of the municipality in the scope of tasks and competences, shaping the platforms of their joint and separate relations. Determining the manner of implementation of tasks and competences of the municipal bodies based on the principle of cooperation, and not the competition between them, should be a legitimate aspiration of the legisla-

${ }^{1}$ See the Constitution of the Republic of Poland of 2 April 1997 (Journal of Laws, item 483, as amended) - hereinafter referred to as the Constitution of the RP. See judgement of the Supreme Administrative Court in Warsaw of 8 February 2005 (OSK 1122/04 , LEX no. 165793), in which the Supreme Administrative Court stated that "article169 par. 1 of the Constitution of the Republic of Poland in conjunction with article 3 par. 1, article 18 par. 2 point 1 , article 21 par. 1 and article 22 par. 1 of the Act on municipal self-government provides for the principle of autonomy of the municipality in the scope of shaping the organizational structure of its bodies, so that it fulfils its tasks to the maximum extent."

${ }^{2}$ Constitution of the French Republic of 4 October 1958 (Constitution du 4 octobre 1958, JORF nº 0238 du 5 octobre 1958, page 9151).

${ }^{3}$ See also judgement of the Supreme Administrative Court of 14 June 1995 (II SA 972/95, LEX no. 821085). 
tor to normatively and factually balance the legal position of both municipal bodies. The search for a normative model for improving the relations between the executive and legislative body in the local community is a current challenge for territorial self-government, because it has a real impact on the management of public affairs in the municipality, which more and more often allow the citizen to actively participate in the life of the selfgovernment community ${ }^{4}$.

\section{BASIC STRUCTURAL AND FUNCTIONAL ISSUES CONCERNING MUNICIPAL BODIES IN BOTH LEGAL ORDERS}

In the Polish legal order pursuant to article 11 of the Act of 8 March 1990 on municipal self-government ${ }^{5 "}$ residents of the municipality make decisions in a general vote (through elections and referendums ${ }^{6}$ ) or through municipal bodies." The municipal bodies are: the municipal council (as the legislative and controlling body) and the head of municipality (mayor, president of the city), performing the function of the executive body. The rules and procedure for conducting elections to municipal bodies are determined by the provisions of the Act of 5 January 2011. The Electoral Code $^{7}$. The council is appointed in general, equal and direct elections held in a secret ballot. The right to vote is vested in persons who have Polish citizenship, if they are 18 years of age and habitually reside in the area of the council's activities. This also applies to EU citizens who do not have Polish citizenship (see article 10 of the Electoral Code). "Councillors

${ }^{4}$ See more on the subject of participation of a resident in government - P. Ardant, B. Mathieu, Droit constitutionnel et institutions politiques, Paris 2015, p. 161 et seq.

${ }^{5}$ See the Act of 8 March 1990 on municipal self-government (consolidated text Journal of Laws of 2017 item 1875 as amended.) - hereinafter referred to as AMSG

${ }^{6}$ On the classic forms of direct democracy in Poland and France see M. Augustyniak, Partycypacja spoteczna $w$ samorzadzie terytorialnym $w$ Polsce, Studium administracyjnoprawne na tle porównawczym [Social participation in territorial self-government in Poland, Administrative and legal study on the comparative background], Warsaw 2017, p. 177.

7 The Act of 5 January of 2011, the Electoral Code (consolidated text: Journal of Laws of 2017, item 15, as amended), hereinafter referred to as the EC. 
are representatives of local interests, and at the same time act as a liaison between the council and voters and their organizations. A councillor can not combine a representative mandate with performing work as part of an employment relationship at the municipal office" .

The executive body in the Polish municipality is the head of municipality (mayor, president of the city), elected in direct, equal and universal elections, in a secret ballot ${ }^{9}$. The legislator indicated that the mayor is the executive body in the municipality in which the seat of the authorities is located in a city located on the territory of this municipality, while in cities with over 100,000 inhabitants the executive body is the city president ${ }^{10}$. Direct election of the executive body guarantees it greater structural and functional independence in relation to the legislative body. It affects the lack of the possibility of dismissal of the executive body by the municipal council. The origin from direct elections of the executive body in the municipality strengthens the legal position of the head of municipality (mayor, president of the city). The term of office of the executive body begins on the commencement of the term of office of the municipal council and expires on the expiration of the term of office of the legislative body ${ }^{11}$. It should be considered that executive bodies in the district and in the voivodeship are elected in indirect elections. The district board is elected by the district council pursuant to article 27 of the Act of 5 June 1998 on district self-government ${ }^{12}$, and the voivodeship board is elected by the voivodeship sejmik (see article 32 of the Act of 5 June 1998 on the voivodeship self-government ${ }^{13}$ ).

Indication of the type of body corresponds to the normative specification of tasks and competences assigned to it by the legislator. Therefore, in the judgement of 12 December 2007 the Voivodeship Administrative Court in Warsaw rightly stated that "The municipal council may not, with-

${ }^{8}$ See W. Skrzydło, Konstytucja Rzeczypospolitej Polskiej. Komentarz [Constitution of the Republic of Poland. Commentary], ed. VII, Warsaw 2013, Lex/el.

${ }^{9}$ See article 471 EC.

${ }^{10}$ See article 26 par. 3 and 4 of the Act on municipal self-government (AMSG).

${ }^{11}$ See Article 26 par. 2 of the AMSG.

${ }^{12}$ See the Act of 5 June 1998 on district self-government (consolidated text Journal of Laws of 2017 item 1868 as amended.) - hereinafter referred to as ADSG.

${ }^{13}$ See the Act of 5 June 1998 on voivodeship self-government (consolidated text Journal of Laws of 2017 item 2096 as amended.) - hereinafter referred to as AVSG. 
out explicit statutory authorization, undertake executive activities assigned, in principle, to the executive body. At the same time, it can not share at its own discretion its legislative and controlling competences with it." ${ }^{14}$ In accordance with article 6 par. 1 of the Act of municipal self-government, the municipal council has been equipped with the competence to resolve all matters reserved for the municipality. The council has exclusive jurisdiction, for example in the field of systemic and organizational matters regarding the adoption of local spatial development plans, financial and budgetary matters, matters concerning property and other (see article 18 par. 2 of the Act on municipal self-government ${ }^{15}$. In the judgement of 24 October 2017 the Voivodeship Administrative Court in Kraków ruled that "Whereas pursuant to article 6 of the Act on municipal self-government the scope of the activities of the municipality includes all public matters of local significance, not reserved by acts for other entities, this provision does not include any presumption of tasks or competences for the benefit of the municipal self-government. As clearly this provision refers to 'public matters of local significance', and the public matter is only such a matter that the legislator passes on to the self-government in the act. In accordance with the fundamental principle of decentralization contained in article 15 par. 1 of the Constitution of the Republic of Poland, territorial self-government performs only tasks delegated to it by the acts and has no right to create public tasks for itself. The tasks of the municipality are always carried out within competences assigned to the authorities of the municipality in the acts." 16

The internal organization and mode of work of the council and its internal bodies (e.g. commissions and teams) are defined by the statutes

${ }^{14}$ See judgement of the Voivodeship Administrative Court in Warsaw of 12 December 2007 (VIII SA/Wa 504/07, LEX no. 460561).

15 The Supreme Administrative Court in the judgement of 25 April 2017 stated that "the scope of activities of the municipality was determined primarily in article 6 par. 1 and article 7 par. 1 of the Act on municipal self-government which indicate that the municipality is independent in the scope of performing the tasks entrusted to it, however, this independence was limited to matters related to the local needs of the community. As a rule, the municipality is not allowed to pursue activities that go beyond the local nature and do not respond to the collective needs of the community" - See. the judgement of the Supreme Administrative Court of 25 April 2017 (I OSK 186/17, LEX no. 2298992).

${ }^{16}$ See judgement of the Voivodeship Administrative Court in Kraków of 24 October 2017 (III SA/Kr 397/17, LEX no. 2381414). 
of the municipality ${ }^{17}$, which are not term-limited. It also contains regulations regarding the organization and operation of the executive body in the municipality. In its judgement of 28 November 2017 the Voivodeship Administrative Court in Gliwice indicated that "The statutes of the municipality may regulate not only those issues that have a separate detailed legal basis in the act, but also all issues related to the functioning of a given municipality, as long as they do not violate the generally applicable provisions of law". ${ }^{18}$ In the Polish legal order, the adoption of the statutes is obligatory. The lack of this act requires taking supervisory measures by the supervisory authorities, especially the governor. The statutes are adopted by a resolution of the municipal council, by a simple majority of votes, in the presence of at least half of the statutory composition of the council, in an open vote ${ }^{19}$. Governor of Lublin Voivodeship indicated in the supervisory decision of 6 July 2016 that "The city council, within the competence to determine the internal organization and the mode of operation of the municipal bodies, can not determine 'duties' for the mayor - they were regulated in the Act on municipal self-government or other regulations. The legislative body may, however, apply to the mayor for such assistance and for reply or taking a position on a specific matter." ${ }^{20}$

${ }^{17}$ The statutes of the municipality belong to the acts of local law of a systemic and organizational nature.

${ }^{18}$ See judgement of the Voivodeship Administrative Court in Gliwice of 28 November 2017 (IV SA/Gl 624/17, LEX no. 2422809). In judgement of 14 May 2013 the Voivodeship Administrative Court in Opole (II SA/Ol 196/13, LEX nr 1316820) stated that: "Article 22 par. 1 of the Act on municipal self-government, according to which the internal organization and the mode of operation of the municipal bodies are determined in the statutes of the municipality, does not limit the subjective scope of the statutes of the municipality only to the internal organization and the mode of operation of the municipal bodies, but at most this provision only defines the minimum scope of regulation of the statutes."

${ }^{19}$ See in supervisory decision of 1 February 2007 Governor of the Podlaskie Voivodeship (NK.II.B.G.0911-18/07, LEX no. 217965) indicated that: "The rule is that resolutions of the municipal council are passed in an open vote. The only exception is the election of the chairperson of the municipal council. The statutes may not extend the number of cases allowing for secret ballot."

${ }^{20}$ See supervisory decision of the Governor of Lubelskie Voivodeship of 6 July 2016 (LEX no. 2106307, NK-I.4131.207.2016.AHor). 
The adoption of the statutes of the municipality is not dependent on the number of residents living in it. This number, however, has an impact on the mode of agreeing possible changes in this act with the Prime Minister, who acts as a supervisory body. In accordance with article 3 of the Act on municipal self-government draft statutes of a municipality with over 300,000 inhabitants ${ }^{21}$ are subject to agreement with the Prime Minister at the request of the minister competent for public administration. The lack of such agreement prevents changes to the statutes, and in the event of their adoption, the supervisory body annuls these regulations as incompatible with the law. One should agree with the view expressed by the Voivodeship Administrative Court in Gliwice of 2 March 2009 that "At the stage of presenting for agreement the draft statutes referred to in article 3 par. 2 of the Act on municipal self-government the governor does not interfere with the supervisory decision, and his/her role, as the supervision authority, may start only from the moment when the municipal council adopts a resolution on the adoption of the agreed draft statutes"22. Entrusting the settlement of disputable issues in this respect to the Council of Ministers raises certain doubts. W. Kisiel rightly claims that "there is no reason to consider article 3 par. 3 as granting lex specialis the municipality the right to appeal to the administrative court against a decision of the Council of Ministers on a dispute between the Prime Minister and the city in the process of agreeing on the statutes"23.

In the French legal order according to regulations of the General Code of Territorial Communities (referred to as $\mathrm{CGCT}^{24}$ ) the municipal council

${ }^{21}$ I share the view expressed by W. Kisiel that the wording of article 3 of the Act on municipal self-government raises legitimate legal doubts. This author claims that "only the statutes of selected (larger) municipalities were included in the conciliation procedure. Only non-legal reasons may explain the making of such a division, which does not comply with the principle of equal treatment of all municipalities. The wording of this regulation does not deserve a positive assessment." - see W. Kisiel, (in:) P. Chmielnicki (ed.), Ustawa o samorzadzie gminnym. Komentarz [Act on the municipal self-government. Commentary.], Warsaw 2013, p. 85.

22 See judgement of the Voivodeship Administrative Court in Gliwice of 2 March 2009 (IV SA/Gl 904/08, LEX no. 533659).

${ }^{23}$ See W. Kisiel, (in:) P. Chmielnicki (ed.), Ustawa o samorządzie gminnym. Komentarz [Act on the municipal self-government. Commentary], Warsaw 2013, p. 86.

${ }^{24}$ Code général des collectivités territoriales (General Code of Territorial Communities, CGCT) - source: https://www.legifrance.gouv.fr. 
has been equipped with a general competence, covering all local matters, not reserved for other territorial communities and government administration $^{25}$. This competence gives the municipality council the opportunity to decide on all matters concerning the organization and functioning of the municipality, if it is not contrary to other legal provisions. The municipal council also has full competence to make decisions on matters where a local interest arises. Therefore, the concept of local interest is extremely important. The administrative court may repeal any decision of the council in which the local interest is not sufficiently justified or does not exist in general ${ }^{26}$. According to the decisions of the Council of State, a local interest occurs when three conditions are cumulatively met: the interest should be public (not private); it should respond to the local needs of residents; the decision of the municipal council can not concern a social or political conflict $^{27}$. The municipal council in France is a legislative and controlling body that resolves local affairs at sessions of the council convened at least once per quarter by the mayor (maire). The mayor is the chairperson of the municipal council and performs all the functions associated with it. Consiel municipal is a collegial body composed solely of councillors elected in accordance with the regulations of Code électoral ${ }^{28}$. According to article L 2 of Code électoral the right to vote for the municipal council is vested in a French citizen and a citizen of the European Union who is not a French citizen who reaches 18 years of age at the latest on the day of the vote, fully enjoys his/her public and political rights and lives in the municipality. In article L44 Code électoral, the French legislator indicated that every French citizen who has a right to vote has a right to stand in elections, subject to cases of incapacity or non-eligibility provided by law. The right to stand in elections is vested in a French citizen and every citizen of the European Union who is 18 or older, resides in a given municipality or at least pays taxes there ${ }^{29}$.

${ }^{25}$ See S. Creusot, Une nouvelle organisation decentralisée de la Republique, Paris 2012, p. 54.

${ }^{26}$ Cf.: J. Ferstenbert, F. Priet, P. Quilichini, Droit des collectivités territoriales, Paris 2016, p. 254 et seq.

${ }^{27}$ See P. Chapsal, Les collectivités territoriales en France, Paris 2015, p. 101 and 102. See judgement CE 1995, Commune de Villeneuve d'Asq.

${ }^{28}$ See Code electoral, source: https://www.legifrance.gouv.fr, access: 24.02.2018

${ }^{29}$ See Bernard Dapogny, Marion Dapogny, L'élu municipal, 4 e édition , Paris 2013, p. 39. In articles: L230, LO230-2, LO230-3 and article L231 Code électoral the legislator 
In the French municipality, the mayor is elected in indirect elections, at the first session of the municipal council, from among councillors who are members of the municipal council ${ }^{30}$. The mayor is at the same time the chairperson of the municipal council. The term of office of the mayor is six years, as is the term of office of the municipal council. The mayor is elected by secret ballot, with absolute majority of votes $^{31}$ in the first two rounds and a relative majority in the third round. In the event of a tied vote the eldest candidate is elected. If he/she refuses to take a position, further elections are organized.

The municipal council/conseil municipal operates on the basis of the internal regulations of the council, which is an act adopted at the beginning of each term of office of the municipal council. It applies until the new term of office of the legislative body. The regulations of the previous council apply until the date of adoption of the new regulations. It should be pointed out that the internal regulations of the council contain, apart from issues of internal organization and functioning of the council, obligatory regulations on specifying CGCT provisions in respect of three procedures: organization of budget debate (see article L. 2312-1 CGCT), conditions for consultation on contracts and public procurement (see Article L. 2121-12 CGCT) and conditions for presenting and responding to interpellations (Article L. 2121-19 CGCT). The internal regulations of the council are subject to appeal to the administrative tribunal ${ }^{32}$. In the French legal system, most issues related to the organization and functioning of the council are included in the provisions of the General Code of

defines a list of persons deprived of the right to stand in elections. This applies, for example, to the judges of appeal courts, entrepreneurs of municipal services, heads of government administration services and officers of subordinate agencies, heads of departmental and regional services - More on this subject, see Pierre Chapsal, Les collectivités territoriales en France, 5 édition, Paris 2015, p. 25.

${ }^{30}$ See E. Landot, Guide du conseil municipal,. Règles, pièges et astuces, Paris 2014, p. 102.

${ }^{31}$ The absolute majority is calculated on the basis of the votes cast in the election of mayor and deputy mayors - See J. Ferstenbert, F. Priet, P. Quilichini, Droit des collectivités territoriales, Paris 2016, p. 265.

${ }^{32}$ The regulations may be subject to déféré préfectoral (the prefect's appeal against the legal act of the territorial community before the administrative court - see B. Faure, Droit des collectivités territoriales, $4^{\mathrm{e}}$ éditon, Paris 2016, p. 123. 
Territorial Communities, which is why a small range of rules remained to be regulated by the regulations.

\section{CLASSIFICATION OF FUNCTIONAL RELATIONS \\ OF MUNICIPAL BODIES IN BOTH LEGAL ORDERS \\ - DE LEGE LATA CONCLUSIONS}

The classification of functional relations between municipal bodies will be presented on the basis of three basic functions: law-making and control as well as executive function.

The law-making function in both legal orders belongs to the municipal council. This function in the French municipal council is carried out within the scope of its decision-making powers, which include, inter alia, the adoption of the budget ${ }^{33}$, approval of its implementation, and discharge to the mayor. In addition, the tasks of the municipal council include, among others, creating and liquidating municipal services and enterprises, adopting local rules of spatial management, developing programmes in the field of housing, education, and activities in the field of housing and cultural policy ${ }^{34}$. It should be emphasized that many competence acts give the council specific tasks and competences in the field of local matters, which are the normative basis for the implementation of the basic objective of the municipality, i.e. satisfying the needs of residents of the municipality. The municipal council also has competences in the scope of giving opinions and filing motions. Whereas in the Polish legal order, the competences of the municipal council of decision-making nature include financial and budgetary issues and competences to legislate, including the adoption of the statutes of the municipality and the statutes of auxiliary units of the municipality. The exclusive competence of the municipal council includes: systemic and organizational matters (e.g. municipal statutes), planning, financial and property matters, and others. The municipal council expresses opinions and conclusions on its own initiative or on the basis of legal regulations.

\footnotetext{
${ }^{33}$ See J. Girardon, Les collectivités territoriales, Paris 2014, p. 94 i n.

${ }^{34}$ See P. Chapsal, Les collectivités territoriales en France, Paris 2015, p. 28.
} 
The control function of the French municipal council is carried out primarily in the exercise of obligation imposed on the mayor to inform the council about the manner of executing the municipal council's resolutions. The mayor is obliged to answer questions (requests and interpellations) by the council or individual councillors. The Council may adopt resolutions expressing its position on the manner of implementation of its resolutions, which is binding on the executive body. In addition, it should be pointed out that the acute control function of the council is the refusal to vote for draft resolutions prepared by the mayor (this concerns in particular the issue of the municipal budget ${ }^{35}$. The mayor and the council should cooperate with each other, because lack of such cooperation is the basis for the dissolution of the council, which results de facto in the dismissal of both bodies. Proper cooperation is also ensured by the electoral system guaranteeing a permanent majority in the council from which the mayor derives ${ }^{36}$. Although the mayor is elected by the municipal council, it has no right to dismiss the mayor ${ }^{37}$. This principle regulates the mutual independence of the municipal bodies in personnel and functional terms. In the Polish legal order, the municipal council controls the head of municipality through the audit commission that exercises control powers granted ex lege to the council. In addition, the control functions of the council include determination of the directions of activities of the head of municipality (mayor, president of the city), approval of reports on his/her activities, and deciding on granting or not granting discharge to the executive body in the municipality ${ }^{38}$. However, these powers can not lead to direct dismissal of the executive body from the function. In addition, it should be men-

35 See B. Dopogny, M. Dopogny, L'élu municipal, Paris 2013, p. 134.

${ }^{36}$ See article L.2122-16 CGCT.

${ }^{37}$ See M. Verpeaux, Les collectivités territoriales en France, Paris 2011, p.102 et seq., see also B. Faure, Droit des collectivités territoriales, $4^{\mathrm{e}}$ éditon, Paris 2016, p. 256.

${ }^{38}$ See judgement of the Voivodeship Administrative Court in Warsaw of 6 October 2006 (III SA/Wa 2504/06, LEX no. 276789), in which the court stated that: "The discharge is one of the most important means of control by the municipal council of the activities of the bodies which implement the previously approved budget. Therefore, it is necessary to comply in detail with the specific procedure for the discharge and to examine whether the resolution of the municipal council, approving primarily the numerical limits of expenditure, has been properly executed by the executive authority". 
tioned that the legislator has decided to appoint an obligatory permanent commission in the municipality for complaints, requests and petitions, whose subject of operation includes consideration of complaints about activities of the head of municipality and municipal organizational units, requests and petitions submitted by citizens ${ }^{39}$. The personal scope of this commission includes councillors, including representatives of all clubs, with the exception of councillors fulfilling the function of a chairperson of the council and deputy chairperson. Limitations on the composition of the commission are similar to those that apply to the audit commission. Detailed rules and mode of operation of the commission for complaints, requests and petitions are specified in the statutes of a given municipality. In the supervisory decision of 7 December 2012 the Mazovian Governor pointed out that "The municipal council performs control functions through the activity of the audit commission, as well as permanent and ad hoc commissions and through interpellations and inquiries of councillors. Control functions of the municipal council in relation to the executive body and its subordinate units are therefore strictly formalized. Councillors can act individually only as part of interpellations or inquiries submitted to the mayor. The activities indicated above are the only measures provided by law that allow councillors to control the executive bodies" ${ }^{40}$.

The executive functions concern the competences and tasks of the head of municipality (mayor, president of the city) and maire. They constitute key issues in the scope of activities of the executive body in the municipality, which has been provided with a certain normative functional independence by defining separate competences in relation to those available to the legislative body in both legal orders.

The competences of the mayor (maire) are carried out directly on behalf of the community or as a result of delegation and on behalf of the state. The competences of the mayor carried out on behalf of the com-

${ }^{39}$ See article $18 \mathrm{~b}$ of the Act on municipal self-government introduced pursuant to the Act of 11 January 2018 on amending certain acts to increase the participation of citizens in the process of electing, operating and controlling certain public bodies (Journal of Laws, item 130). In accordance with article 15 of the said amending act the introduced changes apply to the term of office of territorial self-government units following the term during which the said Act entered into force.

${ }^{40}$ See supervisory decision of the Mazovian Governor of 7 December 2012. 
munity, directly conferred by law include the preparation of draft resolutions and their implementation. This applies, among others, to approval of expenses and supervision over the implementation of income ${ }^{41}$. The mayor is the body to which the CGCT regulations entrust the administration of the territorial community ${ }^{42}$. As the executive body, the mayor also manages the property of the municipal community ${ }^{43}$. In addition, pursuant to article L. 2122-24 CGCT the mayor has the competences of the police, having at its disposal various powers in this field. The mayor together with the legislative body appoints representatives of the council to external bodies and other bodies, in accordance with the law. Their appointment and dismissal are governed by the CGCT regulations and the internal regulations of the council. In the Polish legal order, the executive body has its own competences. Its competences include preparation of draft resolutions of the municipal council and their implementation as well as other tasks defined by law (e.g. issuing order regulations in the municipality in urgent cases $\left.{ }^{44}\right)$. In addition the competences of the head of municipality include, among others, preparation of management of municipal property, drafting development programmes in the manner specified in provisions on the principles of conducting development policy and issues concerning the employment and dismissal of managers of municipal organizational units $^{45}$. Pursuant to article 30 par. 3 of the Act on municipal self-government "in the implementation of the own tasks of municipality, the head of municipality is subject only to the municipal council". This provision ensures independence for the municipality, especially in the scope of

${ }^{41}$ See article L. 2122-21 point 3 CGCT.

${ }^{42}$ See article L. 2122-18 CGCT.

${ }^{43}$ See article L. $2122-21$ point 1 and point 7 CGCT.

${ }^{44}$ See Article 41 par. 2 of the AMSG. See judgement of the Voivodeship Administrative Court in Szczecin of 7 February 2007 (II SA/Sz 1182/06, LEX no. 516652): "Issuing by the head of municipality, the mayor, the city president of order regulations is the only exception to the principle that municipal regulations are established by the municipal council."

${ }^{45}$ See Article 30 par. 2 of the Act on municipal self-government. See on this topic R. Budzisz, (in:) P. Chmielnicki (ed.), Ustawa o samorzadzie gminnym. Komentarz [Act on municipal self-government. Commentary], Warsaw 2013, p. 522 et seq. See judgement of the Voivodeship Administrative Court in Gorzów Wielkopolski of 30 July 2014 (II SA/Go 394/14, LEX no. 1519881). 
implementation of its own tasks. It does not create new relations between the legislative and executive bodies, granting special rights to the municipal council $^{46}$. The municipal council may indicate directions and guidelines to the executive body, the competences of which also include managing the current affairs of the municipality ${ }^{47}$ and representing it in external relations, both in the public as well as private sphere. It is worth emphasizing that the legislative, control and executive competences, without the basis in the acts, can not be transferred to another entity, because it would be against the law.

In the French legal order, in the scope of delegated powers, the mayor may, for the duration of his/her term of office, receive from the municipal council the functions which he/she exercises under authorization. According to the CGCT regulations, the mayor presents the municipal council with reports on the performance of his/her functions. In accordance with article L. 2122-22 CGCT, powers delegated to the mayor comprise 28 categories of affairs, including:

- $\quad$ taking all decisions regarding the preparation, implementation and settlement of contracts and framework agreements, as well as any decisions regarding their amendment, if the funds are budgeted;

- establishing, within the limits set by the municipal council, the rates of road and parking fees,

- making decisions on concluding and changing the subject of the lease for a period not exceeding twelve years;

${ }^{46}$ See R. Budzisz [in:] P. Chmielnicki (ed.), Ustawa o samorządzie gminnym. Komentarz [Act on the municipal self-government. Commentary.], Warsaw 2013, p. 529. This author emphasizes that article 30 par. 3 of the Act on municipal self-government "limits the interference of external entities in the sphere of implementing the own tasks of the municipality. However, this limitation does not apply to supervision instruments that cover the entirety of municipal activities." - ibid. p. 529.

${ }^{47}$ Current affairs require the executive body to act immediately, which means that they can not be reserved for matters falling within the exclusive competence of the council. The division of tasks into current and other tasks should be regulated by the statutes of municipality - see B. Dolnicki, Wptyw nowych zasad wyboru wójta (burmistrza, prezydenta miasta) na relacje $z$ rada gminy [The impact of new rules of election of the head of municipality (mayor, city president) on the relationship with the municipal council], PPP 2007, no. 1-2, p. 81 . 
- in the scope of allocation of municipal property used by municipal public services and carrying out all activities aimed at determining the resources of municipal property;

- applying to any financing body, on the terms set by the municipal council, for granting subsidies;

- giving consent (on behalf of the municipality), in the scope of renewing membership in associations, of which the municipality is a member;

- proceeding (within the limits set by the municipal council) with submitted applications for issuing town planning permits for the demolition, transformation or construction of real estate being the municipal property.

The municipal council may take away delegated powers from the mayor, unless it decided otherwise in its resolution. In the Polish legal order, the municipal council can not delegate its tasks and competences included within its exclusive jurisdiction. It should be emphasized, however, that pursuant to article 18 par. 2 point 9 and 10 of the Act on municipal selfgovernment, the legislative body may set a certain normative framework for the executive body, concerning, for example, passing resolutions on property matters of the municipality exceeding the scope of ordinary management concerning, inter alia, the rules for acquiring, disposing of and encumbering real estate and its lease or rental for a fixed period of more than 3 years or for an indefinite period, if special acts do not provide otherwise; creation, liquidation and reorganization of enterprises, plants and other municipal organizational units and equipping them with property, taking long-term loans and credits and setting the maximum amount of loans and credits. The exclusive competences of the municipal council comprise also determination of the amount up to which the head of municipality can contract liabilities on his/her own. However, these are not powers obtained by the executive body following a delegation made by the municipal council, ergo they are only of executive nature.

It should be emphasized that the mayor exercises certain powers as the official representative of the state ${ }^{48}$. Therefore, the mayor's duties include publishing and implementing acts and ordinances, taking general security

${ }^{48}$ See article L. 2122-27CGCT et seq. 
measures and performance of special functions provided for him/her by the legislator. Performing the order of the prefect or minister, the mayor acts as the official representative of the state ${ }^{49}$. In the Polish legal order, the executive body of the municipality is not a representative of the government administration in the area, although it performs tasks and competences that are also within the scope of commissioned tasks (e.g. elections). The condition for performing these commissioned tasks is to ensure their financing by the government administration ${ }^{50}$. In its judgement of 25 July 2006, the Constitutional Tribunal adjudicated that "Therefore, what is to distinguish own tasks - even if their performance is obligatory - from the commissioned tasks is primarily their local character. Identification of collective needs as local needs has its individual reference when it comes to the needs of only a given self-government unit (e.g. a specific type of cultural tasks related to the history of a given community) as well as categorical one, thus referring to collective needs commonly recognized as those that need to be met by all self-governments, for example, the needs in the field of local public transport, education, and municipal economy (...). The manner of performing own tasks is defined by the legislative and executive bodies of self-government units. They also bear political, legal and financial responsibility for exercising them" 51 .

\section{DIRECTIONS OF CHANGES - DE LEGE FERENDA POSTULATES}

In the Polish and French legal order, determining the proper relations between municipal bodies should be considered a priority task for contemporary self-government. The implementation of own tasks aimed at satisfying local needs determines the efficiency of managing the selfgovernment community and is a determinant of civilization and cultural standards in a given country. The selection of the appropriate organiza-

${ }^{49}$ See decision of the Council of State 19 January 1951, Ville de Menton, Lebon p. 35.

${ }^{50}$ See H. Izdebski, Samorząd terytorialny. Podstawy ustroju i dziatalności [Territorial self-government. The basics of the system and activity], Warsaw 2014, p. 153.

${ }^{51}$ See judgement TK K30/04, OTK-A 2006, no. 7, item 86. 
tional structure of the municipality council and the head of municipality/ mayor corresponds with the expectations of residents of the municipality as those entities that are most interested in co-managing the affairs of the municipality ${ }^{52}$. Therefore, the improvement of the model of municipal bodies should now take into account a wider range of participatory instruments in the local community.

In both legal orders, the executive body of the municipality is a monocratic body. However, the mode of its election in the Polish and French local community is different. The executive body in the French municipality has its source only in the legislative body. The mayor, being a monocratic executive body in the French municipality, gathers deputies in order to make joint decisions within the municipal board.

In the Polish legal order, the tasks and competences of the executive body in the municipality ${ }^{53}$ are identical with the competences and tasks of the mayor, granted by law and implemented on behalf of the local community. An executive body in Polish territorial self-government units has its own competences. Its competencies include preparation of draft resolutions of the board and their implementation (this applies in particular to the budget and long-term financial forecast) and other tasks defined by law. The competences delegated by the council and the competences exercised on behalf of the state, which do not find their equivalent in Polish legal regulations, are a certain difference characteristic of the competences of the mayor.

The classification of functional relations between the municipal bodies based on their three basic functions: law-making and control as well as executive function, leads to the conclusion that in the French municipality the platforms of relations of municipal bodies are wider (a large range of

52 See more on the topic in M. Augustyniak, Partycypacja spoteczna w samorzadzie terytorialnym $w$ Polsce, Studium administracyjnoprawne na tle porównawczym [Social participation in territorial self-government in Poland, Administrative and legal study on the comparative background], Warsaw 2017, p. 115.

${ }^{53}$ More on the tasks and competences of the executive body in the municipality see T. Moll, [in:] B. Dolnicki (ed.), Ustawa o samorządzie województwa. Komentarz [Act on municipal self-government. Commentary], Warsaw 2016, p. 711 et seq. 
delegated powers for the mayor) and based on co-management ${ }^{54}$. Despite the indirect election of the mayor, the French legislator strengthens his/her legal status, not only due to the lack of ability of the municipal council to dismiss the mayor, but above all by granting him/her own competences, performed on behalf of the community, delegated powers (consisting in cooperation between the legislative and executive body) and other competences that the mayor performs on behalf of the state. In all types of competences entrusted to him/her, the mayor has a guaranteed independence to act, which strengthens his/her legal position in relation to the municipal council, still bearing the features of a dominant body.

I think that it is necessary to consider introducing to the Polish legal regulations, on the model of French norms, the catalogue of delegation competences, creating a good platform of relations between the municipal bodies, based on cooperation and shared responsibility for the management of the local community. However, this change requires modification at the level of the Act.

\section{REFEENCES}

Ardant P., Mathieu B. 2015, Droit constitutionnel et institutions politiques, Paris. Augustyniak Magdalena. 2017, Partycypacja społeczna w samorządzie terytorialnym w Polsce, Studium administracyjnoprawne na tle porównawczym

${ }^{54} \mathrm{~W}$. Kisiel points out that "territorial self-government is an organizational structure that can potentially substantially contribute to the decentralization of the administrative function. An element of this decentralization should be equipping both the municipal council and the head of the municipality with adequate competences in the field of administrative law. A clear imbalance in the legal possibilities of the council and the head of municipality to affect the municipal reality can be treated as a temporary situation until the present "dual power" is removed. The municipality is such a small structure that there is no room for the functioning of two mutually opposing decision-making centres. These bodies should actively cooperate with each other to perform the superior function of the municipality, i.e. to meet public needs occurring on a local scale." - W. Kisiel, Wójt gminy:30 -letnia ewolucja i pytania o przysztość [Head of municipality: 30-year evolution and questions about the future], (in:) M. Stec, K. Małysa-Sulińska, Pozycja ustrojowa organów wykonawczych jednostek samorzadu terytorialnego [Systemic position of executive bodies of territorial self-government units], Warsaw 2014, p. 67. 
[Social participation in territorial self-government in Poland, Administrative and legal study on the comparative background], Warsaw.

Budzisz R. 2013, [in:] P. Chmielnicki (ed.), Ustawa o samorządzie gminnym.

Komentarz [Act on municipal self-government. Commentary], Warsaw.

Chapsal P. 2015, Les collectivités territoriales en France, Paris.

Creusot S. 2012, Une nouvelle organisation decentralisée de la Republique, Paris. Dapogny Bernard, Marion Dapogny. 2013, L'élu municipal, $4{ }^{\mathrm{e}}$ édition, Paris.

Dolnicki Bogdan. 2007, Wpływ nowych zasad wyboru wójta (burmistrza, prezydenta miasta) na relację z radą gminy [The impact of new rules of election of the head of municipality (mayor, city president) on the relationship with the municipal council], PPP 2007, no. 1-2, p. 81.

Faure B. 2016, Droit des collectivités territoriales, $4^{\mathrm{e}}$ éditon, Paris 2016, p. 256.

Ferstenbert J., F. Priet, P. Quilichini. 2016, Droit des collectivités territoriales, Paris.

Girardon J. 2014, Les collectivités territoriales, Paris.

Izdebski Hubert. 2014, Samorząd terytorialny. Podstawy ustroju i działalności

[Territorial self-government. The basics of the system and activity], Warsaw.

Kisiel Wiesław. 2013, [in:] P. Chmielnicki (ed.), Ustawa o samorządzie gminnym.

Komentarz [Act on the municipal self-government. Commentary.], Warsaw.

Kisiel Wiesław. 2014, Wójt gminy: 30-letnia ewolucja i pytania o przyszłość

[Head of municipality: 30-year evolution and questions about the future], [in:] M. Stec, K. Małysa-Sulińska, Pozycja ustrojowa organów wykonawczych jednostek samorządu terytorialnego [Systemic position of executive bodies of territorial self-government units], Warsaw 2014.

Landot E. 2014, Guide du conseil municipal,. Règles, pièges et astuces, Paris.

Moll T. 2016, [in:] B. Dolnicki (ed.), Ustawa o samorządzie województwa.

Komentarz [Act on municipal self-government. Commentary], Warsaw.

Skrzydło Wiesław. 2013, Konstytucja Rzeczypospolitej Polskiej. Komentarz

[Constitution of the Republic of Poland. Commentary], ed. VII, Warsaw.

Verpeaux M. 2011, Les collectivités territoriales en France, Paris. 
